\title{
MENUMBUHKAN RASA NASIONALISME MELALUI PENGGUNAAN MODEL PEMBELAJARAN ROLE PLAYING PADA PEMBELAJARAN SEJARAH KELAS XI IPS SMA MUHAMMADIYAH 2 BANJARMASIN
}

\author{
Raudatul Husna \\ Program Studi Pendidikan Sejarah FKIP Universitas Lambung Mangkurat \\ Banjarmasin
}

Email: Raudatulhusnaa26@gmail.com

\begin{abstract}
Abstrak : Nasionalisme adalah suatu paham yang diajarkan untuk mencintai bangsa dan negara atas kesadaran masing-masing warga negara. Menjadi warga negara yang secara bersama-sama untuk mencapai, mempertahankan, dan mengabdikan identitas, juga integritas, serta kemakmuran dan kekuatan bangsa. Nasionalisme merupakan suatu konsep penting yang harus dipertahankan dan menjaga suatu bangsa agar tetap berdiri dengan kokoh. Dengan semangat nasionalisme yang tinggi maka eksistensi suatu negara akan selalu terjaga dari segala ancaman, baik ancaman secara internal maupun ancaman dari eksternal. Sejarah mempunyai kedudukan sebagai pengingat umat manusia untuk selalu sadar dan tidak terjebak ke dalam pengalaman buruk masa lalu yang tercermin dalam cerita sejarah. Dalam konteks nasionalisme sejarah memberi peringatan kepada kita tetang pentingnya memahami identitas kebangsaan yang kita miliki dengan cara menengok kembali pada masa lalu pada waktu identitas tersebut terbentuk.
\end{abstract}

\section{PENDAHULUAN}

Dalam pendidikan tidak bisa dilepaskan dari yang namanya proses pembelajara. Belajar merupakan suatu proses interaksi antara stimulus dan respon yan dilakukan oleh seseorang untuk memperoleh suatu perubahan yang baru, sebagai hasil pengalamnnya sendiri dengan interaksi dengan lingkungannya. generasi muda merupakan sosok individu yang sangat berkompeten dalam menentukan maju mundurnya suatu bangsa, karena hal tersebut akan membawanya kearah kemajuan diri dari bangsanya. Setiap jenjang sekolah diharapkan mampu menumbuhkan rasa nasionalisme kepada peserta didiknya. Sebab pendidikan mempunyai peran yang strategis untuk membentengi peserta didik sebagai penerus bangsa, yang mampu saling menghormati masyarakat yang ada, diharapkan mapu menyiapkan peserta didik sebagai warga negara yang baik, bertanggung jawab, dan juga mampu menjadi warga negara yang mau dan mampu membela bangsanya dan mengamankan aset-aset bangsanya.

Mempelajari sejarah tidak hanya sekedar belajar mengenai masa lalu saja. Namun mempelajari sejarah bisa menjadi bahan pertimbangan dalam melakukan sesuatu didepannya.Sejarah bukan hanya menghafal nama dan tahun saja. 
Sejarah pada hakikatnya yang terpenting adalah mempelajari peristiwa-peristiwa yang terjadi pada masa lampau. Karena peristiwa yang satu bisa berhubungan dengan peristiwa yang lain. Mempelajari sejarah tidak bisa lepas dari "sebabakibat". Sebuah peristiwa terjadi karena ada sebab, dan sebuah peristiwa juga mempunyai akibat. Hikamah dari peristiwa sejarah yang terjadi bisa menjadi gambaran untuk kita menentukan langkah kedepan supaya peristiwa buruk dimasa lalu tidak terjadi lagi.

Disetiap aktivitas pendidikan tedapat faktor utama yang dapat mempengaruhi dalam pola interaksi yang terletak pada pendidik dengan segala kelebihan dan kekurangannya. Mengetahui betapa pentingnya rasa Nasionalisme, maka dari itu sebagai pendidik dapat memilih metode yang benar agar apa yang ingin dicapai dapat terwujud.

\section{KONSEP NASIONALISME DALAM PEMBELAJARAN SEJARAH}

Nasionalisme berasal dari kata nation (bangsa). Nasionalisme adalah suatu paham atau ajaran untuk mencintai bangsa dan negara atas kesadaran keanggotaan/warga negara yang secara potensial bersama-sama mencapai, mempertahankan, dan mengabdikan identitas, integritas, kemakmuran dan kekuatan bangsanya. Nasionalisme merupakan suatu paham yang mengutamakan persatuan dan kebebasan bangsa. Nasionalisme memuat beberapa prinsip yaitu: kesatuan, kebebasan, kesamaan, kepribadian, dan prestasi. Nasionalisme juga dapat diartikan sebagai perpaduan dari rasa kebangsaan dan paham kebangsaan. Dengan semangat kebangsaan yang tinggi, kekhawatiran akan terjadinya ancaman terhadap keutuhan bangsa akan dapat terhindarkan.

Nasionalisme adalah manifestasi kesadaran bernegara atau semangat benegara. Nasionalisme itu berkembang bagaimana penerapan cara berpikir nasional. Berpikir nasional dapat juga merupakan antetis terhadap cara pikir kedaerahan atau golongan (Muljana, Slamet, 2008: 3-7). Menurut Grendi Hendrastomo (2005) Nasionalisme merupakan sebuah paham yang muncul tatkala kita diharuskan harus memilihpada diri kita akan status kebangsaan. Secara umum nasionalisme muncul tatkala seorang dihadapkan pada dua pilhan yang mengharuskan memilih hal yang berkenaan dengan kewarganegaraan, suatu kelompok, yang secara hayal ada keterkaitan. Sementara menurut Sartono Kartodirjo, bahwa nasionalisme memuat tentang kesatuan/unity, kebebasan/ liberty, kesamaan/ equality, demokrasi, kepribadian nasional serta prestasi kolektif (Kartono, Satodirjo, 1999: 60)

Nasionalisme adalah satu paham yang menciptakan dan mempertahankan kedaulatan sebuah negara (nation) dengan mewujudkan satu konsep identitas bersama untuk sekelompok manusia. Substansi nasionalisme Indonesia mempunyai dua unsur: pertama; kesadaran mengenai persatuan dan kesatuan bangsa Indonesia yang terdiri atas banyak suku, etnik, dan agama. 
Kedua, kesadaran bersama bangsa Indonesia dalam menghapuskan segala bentuk penjajahan dan penindasan dari bumi Indonesia (Susanto, Heri, 2017: 39).

Berdasarkan beberapa pendapat di atas, nasionalisme adalah suatu paham yang diajarkan untuk mencintai bangsa dan negara atas kesadaran masing-masing warga negara. Menjadi warga negara yang secara bersama-sama untuk mencapai, mempertahankan, dan mengabdikan identitas, juga integritas, serta kemakmuran dan kekuatan bangsa. Nasionalisme merupakan suatu konsep penting yang harus dipertahankan dan menjaga suatu bangsa agar tetap berdiri dengan kokoh. Dengan semangat nasionalisme yang tinggi maka eksistensi suatu negara akan selalu terjaga dari segala ancaman, baik ancaman secara internal maupun ancaman dari eksternal.

Pembelajaran adalah membelajarkan siswa menggunakan asas pendidikan maupun teori belajar yang merupakan penentu utama keberhasilan pendidikan. Pembelajaran merupakan komunikasi dua arah, mengajar dilakukan pihak guru sebagai pendidik, sedangkan belajar dilakukan oleh peserta didik (Sanggala, Syaiful, 2006: 61). Sebagai suatu proses kerja sama, pembelajaran tidak hanya menitikberatkan pada kegiatan guru atau kegiatan siswa saja, akan tetapi guru dan siswa secara bersama-sama berusaha mencapai tujuan pembelajaran yang telah ditentukan (Sanjaya, 2008:26).

Pembelajaran sejarah adalah proses dimana seseorang atau sekelompok orang melakukan aktivitas belajar-mengajar, didalamnya memuat pelajaran tentang kehidupan manusia di masa lampau dalam bentuk peristiwa, dilakukan dengan cara komunikasi dua arah sehingga pesan/nilai dari sebuah peristiwa tersebut dapat tersampaikan (Susanto, Heri \& Helmi Akmal, 2019: 28).

Pada dasarnya pelajaran sejarah sejauh ini cukup dapat memberikan manfaat yang cukup berarti bagi upaya menumbuhkan jiwa nasionalisme siswa. Siswa yang masih hidup dalam dunia yang penuh kebimbangan, keraguan, dan ketidakdewasaan memang harus diberikan dorongan untuk mengenal lebih dini apa sebenarnya tujuan mereka mendapatkan pendidikan di sekolah. Pendidikan sejarah tidak lepas dari kurikulum yang mengarahkan remaja untuk memahami posisinya sebagai warga negara yang memiliki hak dan kewajiban tertentu. Pada dasarnya mempelajari sejarah bukan hanya sekedar mempelajari mengenai masa lalu, namun mempelajari sejarah bisa menjadi bahan pertembangan untuk melakukan sesuatu kedepannya. Pembelajaran sejarah bukan hanya sekedar menghafal tahun dan nama saja. Namun sejarah pada hakekatnya adalah mempelajari peristiwa-peristiwa yang terjadi dimasa lampau. Pembelajaran Sejarah tidak bisa lepas dari sebab-akibat, sebuah peristiwa sejarah yang sudah terjadi bisa menjadi gambaran kita untuk menentukan langkah kedepan agar peristiwa buruk dimasa lalu tidak terulang lagi, jadi dengan adanya pembelajaran sejarah menjadi sebuah pertimbangan untuk kita melangkah kedepan.

Pada konteks ini, sejarah berperan dalam menanamkan konsepkonsep; 
nasionalisme, persatuan, solidaritas dan integritas nasional tersebut. Bagi peserta didik tidak bisa dipungkiri bahwa pembelajaran sejarah di sekolah adalah cara terbaik untuk menanamkan konsepkonsep dan nilai tersebut. Pembelajaran merupakan jantung dari proses pendidikan dalam suatu institusi pendidikan. Kualitas pembelajaran bersifat kompleks dan dinamis, dapat dipandang dari berbagai persepsi dan sudut pandang melintasi garis waktu. Pada tingkat mikro, pencapaian kualitas pembelajaran merupakan tanggungjawab profesional seorang guru, misalnya melalui penciptaan pengalaman belajar yang bermakna bagi siswa dan fasilitas yang didapat siswa untuk mencapai hasil belajar yang maksimal (Susanto, Heri, 2014: 42-43).

Sejarah mempunyai kedudukan sebagai pengingat umat manusia untuk selalu sadar dan tidak terjebak ke dalam pengalaman buruk masa lalu yang tercermin dalam cerita sejarah. Dalam konteks nasionalisme sejarah memberi peringatan kepada kita tetang pentingnya memahami identitas kebangsaan yang kita miliki dengan cara menengok kembali pada masa lalu pada waktu identitas tersebut terbentuk. Kedudukan sejarah sebagai subject matter telah ada sejak lama, akan tetapi kedudukan sejarah sebagai pendefinisi jiwa zaman belum banyak dipahami oleh pengajar sejarah terlebih peserta didik.

\section{MENUMBUHKAN RASA NASIONALISME DENGAN PENGGUNAAN MODEL PEMBELAJARAN ROLE PLAYING DALAM PEMBELAJARAN SEJARAH}

Menurut Arends (dalam Agus Suprijuno, 2013: 46) model pembelajaran mengacu pada pendekatan yang digunakan termasuk di dalamnya tujuantujuan pembelajaran, tahap-tahap dalam kegiatan pembelajaran, lingkungan pembelajaran dan pengelolaan kelas.

Role Playing (bermain peran) sebagai suatu model pembelajaran bertujuan untuk membantu siswa menemukan diri (jati diri) didunia sosial dan memecahkan dilema dengan bantuan kelompok (Uno, Hamzah B, 2009: 26). Bermain peran (role playing) adalah cara menyajikan suatu bahan pelajaran atau materi pelajaran dengan mempertunjukkan, mempertontonkan, atau memperlihatkan suatu keadaan atau peristiwa-peristiwa yang dialami orang, cara atau tingkah laku dalam hubungan sosial. Jadi dengan kata lain bermain peran (role playing) adalah metode mengajar yang dalam pelaksanaannya peserta didik mendapat tugas dari guru untuk mendramatisasikan suatu situasi sosial yang mengandung suatu problem atau masalah, agar peserta didik dapat memecahkan suatu masalah yang muncul dari suatu situasi sosial tersebut (Hamalik, Oemar, 2003 :104).

Menurut Santoso (2011: 32) yang mengatakan bahwa model role playing adalah suatu cara penguasaan bahan-bahan pelajaran melalui pengembangan imajinasi dan penghayatan siswa yang di dalamnya terdapat aturan, tujuan, dan unsur senang dalam melakukan proses belajar mengajar.

Pada model pembelajaran ini peserta didik menjadi subjek utama. 
Mereka secara aktif melaksanakan praktik komunikasi dengan kelompoknya dalam situasi tertentu sesuai tema masing-masing.Melalui role playing peserta didik diharapkan bisa mengeksplorasi perasaannya; mendapatkan wawasan tentang nilai, sikap, dan persepsinya tentang sejarah perjuangan bangsa; mengembangkan sikap dan ketrampilan dalam memecahkan masalah yang sedang dihadapi; serta mengeksplorasi inti dari masalah yang diperankan. Langkah-langkahnya sebagai berikut. Secara berkelompok peserta didik mempelajari skenario sesuai tema yang diberikan guru. Setiap kelompok memerankan skenario yang disusun berdasarkan urutan tema, sedangkan kelompok lain memperhatikan. Setelah selesai peserta didik diberi lembar kerja untuk melakukan penilaian atas penampilan tiap kelompok dan menyampaikan kesimpulan yang dikuatkan oleh guru. Contoh penerapan model ini dalam pembelajaran sejarah:

- Langkah 1;

Menghangatkan situasi dengan cara, mengidentifikasi dan memaparkan masalah, menjelaskan masalah, menafsirkan masalah dan menjelaskan role playing.

Aplikasi; guru memaparkan topik yang akan diperankan, menjelaskan masalah-masalah yang terjadi dengan topik tersebut. Misalnya pada materi peristiwa Rengasdengklok.

- Langkah 2;

Memilih partisipan dengan cara, menganalisis peran dan memilih pemain yang akan melakukan peran.

Aplikasi; setelah memahami masalah dan peristiwa sejarahnya, selanjutnya guru bersama siswa menganalisis peran dan memilih pemeran pada tiap tokoh.

- Langkah 3;

Mengatur setting, mengatur sesi tindakan dan menegaskan peran.

Aplikasi; guru bersama siswa mengatur tindakan-tindakan yang akan dilakukan oleh pemeran.

- Langkah 4;

Mempersiapkan peneliti, memutuskan apa yang diamati dan membagi tugas pengamatan.

Aplikasi; pada kegiatan ini harus dipersiapkan observer untuk mengamati kegiatan role play yang dilakukan, siswa yang tidak bertugas untuk memainkan peran bisa berperan sebagai observer. Observasi akan lebih efektif lagi apabila sebelumnya telah disiapkan lembar observasi yang akan 
digunakan siswa. Observer tidak bertugas untuk menilai apakan pemeran tiap tokoh sudah memerankan tikoh dengan baik atau belum, melainkan mengamati bagaimana peran tiap tokoh dalam peristiwa sejarah, mengapa tokoh tersebut bertindak dan apa atau bagaimana akibat dari tindakan yang dilakukan.

- Langkah 5;

Pemeranan (kegiatan inti sosio drama).

Aplikasi; tiap pemeran yang ditugaskan untuk memerankan masing-masing tokoh memerankan sesuai skenario yang dibuat. Siswa yang berperan sebagai observer melakukan pengamatan sesuai lembar observasi.

- Langkah 6;

Diskusi dan evaluasi, mereview drama, mendiskusikan fokus utama dan mengembangkan peran.

Aplikasi; setelah selesai kegiatan drama, siswa diminta untuk mendiskusikan pemeranan yang telah dilakukan, menyangkut; peran tiap tokoh, sebab dari tindakan yang dilakukan dan akibat dari tindakan tersebut. Selanjutnya siswa diminta untuk memperbaiki pemeranan dan bersiap untuk memerankan kembali.

- Langkah 7;

Pemeranan kembali, memainkan kembali peran yang telah diperbaiki sesuai dengan masukan siswa dalam kegiatan diskusi sebelumnya.

Aplikasi; siswa memerankan kembali drama yang telah diperbaiki, tahap ini juga bisa dilakukan dengan mengganti pemeran dari tiap tokoh.

- Langkah 8;

Diskusi dan evaluasi tahap kedua.

Aplikasi; siswa kembali mendiskusikan pemeranan kedua

- Langkah 9;

Berbagi dan menggenarilasi pengalaman.

Aplikasi; siswa diminta untuk menghubungkan situasi yang terjadi dengan tindakan yang dilakukan oleh tiap tokoh. Siswa juga diminta untuk mengidentifikasi nilai-nilai sosial-psikologis dari peristiwa yang diperankan, misalnya mengapa terjadi perbedaan pandangan antara golongan muda dan golongan tua, atau mengapa terjadi perpecahan antara golongan tua dan golongan muda (Susanto, Heri, 2014: 109-111)

Kelebihan dalam model pembelajaran Role Playing ini untuk memberikan 
kesan yang kuat dan juga memberikan dampak yang lama dalam ingatan peserta didik, model ini juga membuat semua peserta didik berpartisipasi. Model Role Playing juga memberikan pengalaman yang menarik dan menyenangkan bagi peserta didik yang sulit dilupakan, memberikan pengalaman baru untuk peserta didik. Mampu membangkitkan gairah dan semangat optimisme dalam diri peserta didik, adanya kelas yang antusias dan dinamis serta juga menumbuhkan kesetiakawanan sosial yang tinggi. Peserta didik juga dapat menghayati peristiwa perjuangan bangsa Indonesia tersebut, dan juga mampu memetik butirbutir hikmah yang terkandung dalam peristiwa tersebut.

Dalam model pembelajaran Role Playing ini juga dapat menumbuhkan sikap menghargai jara para pahlawan, mengisi kemerdekaan dengan kegiatan yang positif, belajar dengan rajin dan tekun untuk mengembangkan diri secara maksimal, menjaga peninggalan sejarah, memperkaya khasanah budaya bangsa melalui berbagai kegiatan, serta juga dapat menjaga persatuan dan kesatuan. Selain itu dapat meningkatkan sikap meneladani kepahlawanan, dan patriotisme yaitu rela berkorban, berjiwa besar, sabar, saling memaafkan, suka bekerja keras, bertanggung jawab, toleransi, menghargai pendapat orang lain, serta juga menjaga lingkungan dengan sebaik-baiknya.

\section{PENUTUP}

Nasionalisme adalah suatu paham atau ajaran untuk mencintai bangsa dan negara atas kesadaran keanggotaan/warga negara yang secara potensial bersama-sama mencapai, mempertahankan, dan mengabdikan identitas, integritas, kemakmuran dan kekuatan bangsanya. Nasionalisme merupakan suatu paham yang mengutamakan persatuan dan kebebasan bangsa. Nasionalisme memuat beberapa prinsip yaitu: kesatuan, kebebasan, kesamaan, kepribadian, dan prestasi. Nasionalisme juga dapat diartikan sebagai perpaduan dari rasa kebangsaan dan paham kebangsaan. Dengan semangat kebangsaan yang tinggi, kekhawatiran akan terjadinya ancaman terhadap keutuhan bangsa akan dapat terhindarkan.

Dengan menggunakan Model Pembelajaran Role Playing ini diharapkan mampu menumbuhkan rasa Nasionalisme sebab kelebihan model ini Peserta didik dapat menghayati peristiwa perjuangan bangsa Indonesia tersebut, dan juga mampu memetik butir-butir hikmah yang terkandung dalam peristiwa tersebut.

\section{DAFTAR PUSTAKA}

Buku:

Hamalik, Oemar. Kurikulum dan Pembelajaran. Bumi Aksara. 2003.

Kartodirdjo, Sartono. Multidimensi Pembangunan Bangsa Etos Nasionalisme dan Negara Kesatuan. Kanisisus. 1999. 
Muljana, Slamet. Kesadaran Nasional; Dari Kolonialisme Sampai Kemerdekaan. Lkis Pelangi Aksara. 2008.

Sanggala, Syaiful. Konsep dan Makna Pembelajaran. Alfabeta. 2006.

Sanjaya, Wina. Strategi Pembelajaran Berorientasi Standar Proses Pendidikan. Kencana Prenada Media. 2006.

Suprijuno, Agus. Cooperative Learning Teori dan Aplikasi PAIKEM. Pustaka Pelajar. 2013.

Susanto, Heri. Seputar Pembelajaran Sejarah: Isu, Gagasan, dan Strategi Pembelajaran. Aswaja Pressindo. 2014.

Susanto, Heri and Helmi Akmal. Media Pembelajaran Sejarah Era Teknologi Informasi (Konsep Dasar, Prinsip Aplikatif, dan Perancangannya). Program Pendidikan Sejarah FKIP Universitas Lambung Mangkurat 2019.

Uno, Hamzah B. Perencanaan Pembelajaran. Jakarta: Bumi Aksara. 2008.

Jurnal

Susanto, Heri. "Pemahaman Sejarah Daerah dan Persepsi Terhadap Keberagaman Budaya dalam Membina Sikap Nasionalisme (Studi Korelasi pada Mahasiswa Pendidikan SejarahFKIP UNLAM)": Jurnal Program Studi Pendidikan Sejarah, 9,2 (2017): 39-50. 